\title{
Simultaneous acquisition of PAR and PAIN spectra
}

\section{Journal Article}

\section{Author(s):}

Nielsen, Anders B.; Szekely, Kathrin; Gath, Julia; Ernst, Matthias (D); Nielsen, Niels C.; Meier, Beat H.

Publication date:

2012-04

Permanent link:

https://doi.org/10.3929/ethz-b-000047495

Rights / license:

In Copyright - Non-Commercial Use Permitted

\section{Originally published in:}

Journal of Biomolecular NMR 52(4), https://doi.org/10.1007/s10858-012-9616-7 


\title{
Simultaneous acquisition of PAR and PAIN spectra
}

\author{
Anders B. Nielsen • Kathrin Székely • \\ Julia Gath • Matthias Ernst • Niels Chr. Nielsen • \\ Beat H. Meier
}

Received: 26 November 2011 / Accepted: 7 February 2012/Published online: 28 February 2012

(C) Springer Science+Business Media B.V. 2012

\begin{abstract}
We present a scheme that allows the simultaneous detection of PAR and PAIN correlation spectra in a single two-dimensional experiment. For both spectra, we obtain almost the same signal-to-noise ratio as if a PAR or PAIN spectrum is recorded separately, which in turn implies that one of the spectra may be considered additional information for free. The experiment is based on the observation that in a PAIN experiment, the PAR condition is always also fulfilled. The performance is demonstrated experimentally using uniformly ${ }^{13} \mathrm{C},{ }^{15} \mathrm{~N}$-labeled samples of $\mathrm{N}-\mathrm{f}-\mathrm{MLF}-\mathrm{OH}$ and ubiquitin.
\end{abstract}

\section{Keywords Solid-state NMR $\cdot$ PAR $\cdot$ PAIN $\cdot$ CP-MAS}

Magic-angle-spinning (MAS) solid-state NMR is an emerging spectroscopic technique for obtaining protein structures at atomic-resolution (Castellani et al. 2002; Franks et al. 2008; Jehle et al. 2010; Lange et al. 2005; Loquet et al. 2008; Manolikas et al. 2008; Nieuwkoop et al. 2009; Zhang et al. 2010; Zhou et al. 2007; Böckmann 2008; Huber et al. 2011). It is particularly promising for

Electronic supplementary material The online version of this article (doi:10.1007/s10858-012-9616-7) contains supplementary material, which is available to authorized users.

A. B. Nielsen · K. Székely · J. Gath · M. Ernst ·

B. H. Meier $(\square)$

Physical Chemistry, ETH Zürich, Wolfgang-

Pauli-Strasse 10, 8093 Zürich, Switzerland

e-mail: beme@ethz.ch

N. Chr. Nielsen

Interdisciplinary Nanoscience Center (iNANO) and Department of Chemistry, Center for Insoluble Protein Structures (inSPIN), University of Aarhus, 8000 Aarhus C, Denmark non-crystalline systems including membrane proteins (Cady et al. 2010; Mani et al. 2006; Todokoro et al. 2006; Traaseth et al. 2009), prions and amyloid fibrils (Nielsen et al. 2009; Wasmer et al. 2008; Ferguson et al. 2006; Iwata et al. 2006; Jaroniec et al. 2004; van Melckebeke et al. 2010), and their complexes with small molecules (Schütz et al. 2011). Using higher magnetic fields, improved isotope-labeling procedures and pulse sequences, the size of the investigated proteins has been increasing steadily over the past decade (Böckmann 2008). However, atomic-resolution structure determination of large systems, tentatively defined as proteins with more than 100 residues (Gath et al. 2011; Habenstein et al. 2011; Higman et al. 2009; Lange et al. 2010; Renault et al. 2011; Franks et al. 2010) remains presently limited by spectral resolution and the low sensitivity and correspondingly long experimental times of the experiments that yield structural restraints.

For the collection of structural restraints in solid proteins, second-order recoupling schemes (Scholz et al. 2007; Grommek et al. 2006) are typically applied to avoid or reduce the effects of dipolar truncation (Bayro et al. 2009). Second-order methods using a common third spin to assist dipolar recoupling between two rare nuclei, namely the homonuclear proton-assisted recoupling (PAR) (De Paepe et al. 2008) and heteronuclear proton-assisted insensitive nuclei (PAIN) (Lewandowski et al. 2007; de Paepe et al. 2011) experiments, are an important pair of experiments in the context of structure determination (van Melckebeke et al. 2010; De Paepe et al. 2008). In these experiments, continuous-wave spin-lock fields are applied on the passive $\left({ }^{1} \mathrm{H}\right)$ and active spins $\left({ }^{13} \mathrm{C}\right.$ and/or $\left.{ }^{15} \mathrm{~N}\right)$. Both techniques have been shown to be effective for measuring long-range restraints at varying MAS frequencies from 10 to $65 \mathrm{kHz}$ on uniformly labeled samples (Lewandowski et al. 2009; Bertini et al. 2010; De Paepe et al. 2008; de Paepe et al. 
2011). Typical measurement times of proteins amount to a few days for each of the experiments.

In this Communication, we show an experimental setup for simultaneously measuring ${ }^{13} \mathrm{C}-{ }^{13} \mathrm{C}$ PAR and ${ }^{15} \mathrm{~N}-{ }^{13} \mathrm{C}$ PAIN correlation spectra. We take advantage of third-spin assisted recoupling to enable homonuclear and heteronuclear coherence transfer concurrently, thus saving valuable measurement time. The experiment is based on two observations: (1) due to the relatively small number of ${ }^{15} \mathrm{~N}$ spins in uniformly labeled proteins, initial adiabatic crosspolarization (CP) (Hediger et al. 1995) to ${ }^{15} \mathrm{~N}$ and ${ }^{13} \mathrm{C}$ can be performed simultaneously without significantly reduced intensity when compared to the individual ${ }^{1} \mathrm{H}-{ }^{13} \mathrm{C}$ and ${ }^{1} \mathrm{H}-{ }^{15} \mathrm{~N}$ CP experiments. Similar approaches have been implemented before (Linser et al. 2011; Herbst et al. 2008). (2) the fulfillment of the PAIN condition automatically ensures the fulfillment of the PAR condition. Thus, whenever the PAIN ${ }^{15} \mathrm{~N}-{ }^{13} \mathrm{C}$ transfer is effective, ${ }^{13} \mathrm{C}-{ }^{13} \mathrm{C}$ coherence transfer will also occur.

The pulse sequence for the simultaneous PAIN/PAR experiment is given in Fig. 1a. After simultaneous adiabatic ${ }^{1} \mathrm{H}-{ }^{13} \mathrm{C}$ and ${ }^{1} \mathrm{H}-{ }^{15} \mathrm{~N} \mathrm{CP}$, both the ${ }^{13} \mathrm{C}$ and ${ }^{15} \mathrm{~N}$ magnetization are frequency labeled in $\mathrm{t}_{1}$ before the simultaneous ${ }^{13} \mathrm{C}-{ }^{13} \mathrm{C}$ and ${ }^{15} \mathrm{~N}-{ }^{13} \mathrm{C}$ polarization transfer. This simultaneous mixing is mediated by employing the coinciding PAR and PAIN condition. Note that the only difference between a standard

\section{a}

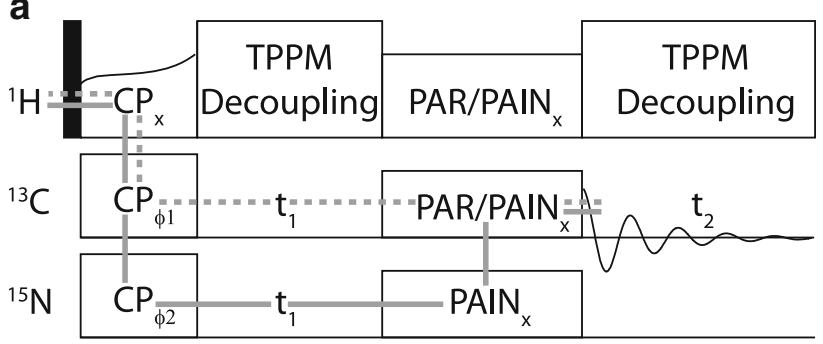

b

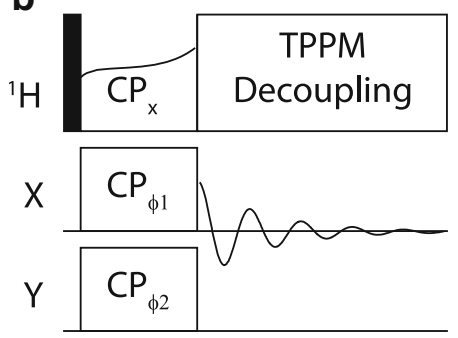

Fig. 1 a Pulse sequence for simultaneous acquisition of two-dimensional PAR and PAIN correlation experiments with TPPI applied to $\varphi_{1}$ and $\varphi_{2}$. The broken and solid gray lines represent the magnetization pathways for the PAR and PAIN experiments, respectively. A four step phase-cycling on $\mathrm{CP}$ is utilized given by $\varphi_{1}=\varphi_{2}=\{x, x,-x,-x\}$ and receiver phase $\varphi_{\text {det. }}=\{x,-x,-x, x\}$. The black bars indicate $\pi / 2$ pulses using phases $(\mathrm{y},-\mathrm{y}, \mathrm{y},-\mathrm{y})$. b Pulse sequence employed for testing simultaneous ${ }^{1} \mathrm{H}-{ }^{13} \mathrm{C}$ and ${ }^{1} \mathrm{H}-{ }^{15} \mathrm{~N}$ cross polarization transfer. $\mathrm{X}$ and $\mathrm{Y}$ correspond, in our experiments, to either ${ }^{13} \mathrm{C}$ - or ${ }^{15} \mathrm{~N}$-channel
Fig. 2 Experimental efficiency of the CP step for $U-{ }^{13} \mathrm{C},{ }^{15} \mathrm{~N}$ labeled ubiquitin using the pulse sequence in Fig. 1b with a, c acquiring the ${ }^{13} \mathrm{C}$ - (X channel in Fig. 1b) and b, $\mathbf{d}$ the ${ }^{15} \mathrm{~N}$ channel. $\mathbf{a}$ and $\mathbf{b}$ show the $\mathrm{CP}$ transfer efficiency (integrated ${ }^{13} \mathrm{C}$ and ${ }^{15} \mathrm{~N}$ signals over full spectral region, respectively) as a function of the mixing time employing no $\mathrm{rf}$ irradiation on the third Y channel for the black curves and rf irradiation on both channels (simultaneous CP) for the red curves. $\mathbf{c}$ and $\mathbf{d}$ illustrate, in black, experimental spectra for best CP performance without $\mathrm{rf}$ irradiation on the $\mathrm{Y}$ channel for ${ }^{13} \mathrm{C} \mathrm{CP}(\mathbf{c})$ and ${ }^{15} \mathrm{~N}$ $\mathrm{CP}(\mathbf{d})$. The green curves show the difference between optimized conventional CP (the black spectra) and simultaneous CP. See supporting material Table S1 for a complete list of experimental parameters
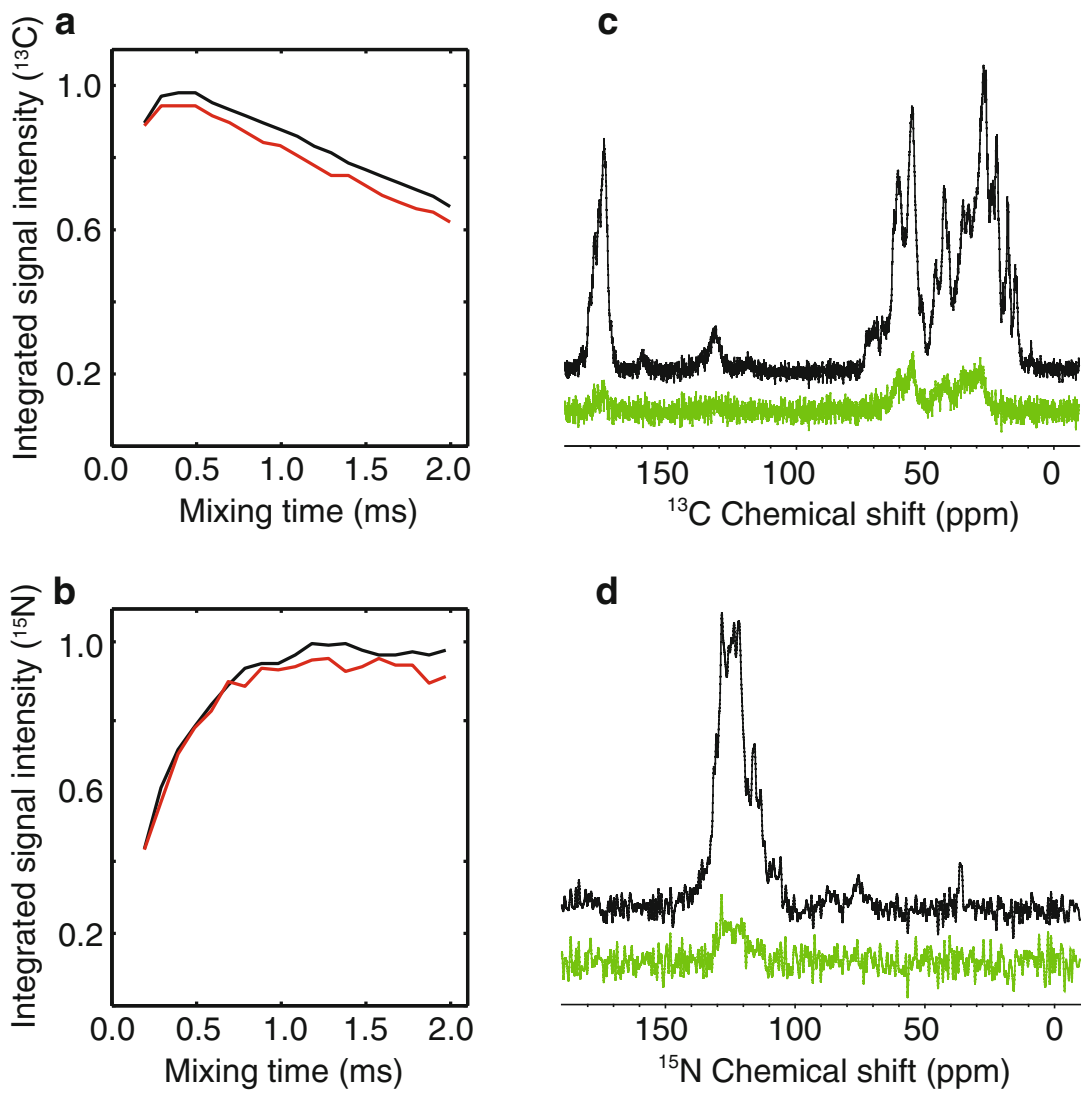
2D PAIN pulse sequence and the one in Fig. 1a is an additional rf field on ${ }^{13} \mathrm{C}$ during the initial $\mathrm{CP}$. The raw 2Dspectrum will contain both ${ }^{15} \mathrm{~N}-{ }^{13} \mathrm{C}$ and ${ }^{13} \mathrm{C}-{ }^{13} \mathrm{C}$ correlation peaks. In order to distinguish between heteronuclear and homonuclear correlation peaks, two experiments are performed which differ by a $\pi$ phase change for the ${ }^{15} \mathrm{~N}$ rf field under $\mathrm{CP}, \varphi_{2}$. The sum of the experiments will result in the PAR spectrum, the difference in the PAIN spectrum. We note that the spectral width is the same in both the ${ }^{15} \mathrm{~N}$ and ${ }^{13} \mathrm{C}$ dimensions but this has no effect on the signal-tonoise ratio of the spectra and could only become relevant in cases where the acquisition is time-limited, e.g. for very high signal-to-noise ratio. Furthermore, the decay-time of the FID is similar for ${ }^{13} \mathrm{C}$ and ${ }^{15} \mathrm{~N}$ signals.
Fig. 3 Experimental 2D $400 \mathrm{MHz}$ spectra for $U_{-}{ }^{13} \mathrm{C},{ }^{15} \mathrm{~N}$-labeled ubiquitin employing the pulse sequence shown in Fig. 1a. The PAR $\mathbf{a}$ and PAIN, $\mathbf{b}$ spectra are obtained by adding or subtracting the spectra given in Fig. S2a and Fig. S2b. See supporting material Table $\mathrm{S} 2$ for experimental parameters. The indirect ${ }^{15} \mathrm{~N}$ dimension for the PAIN spectrum was processed as ${ }^{13} \mathrm{C}$ data and then rescaled by a factor of $\gamma_{13_{C}} / \gamma_{13_{N}} \sim 2.5$ a

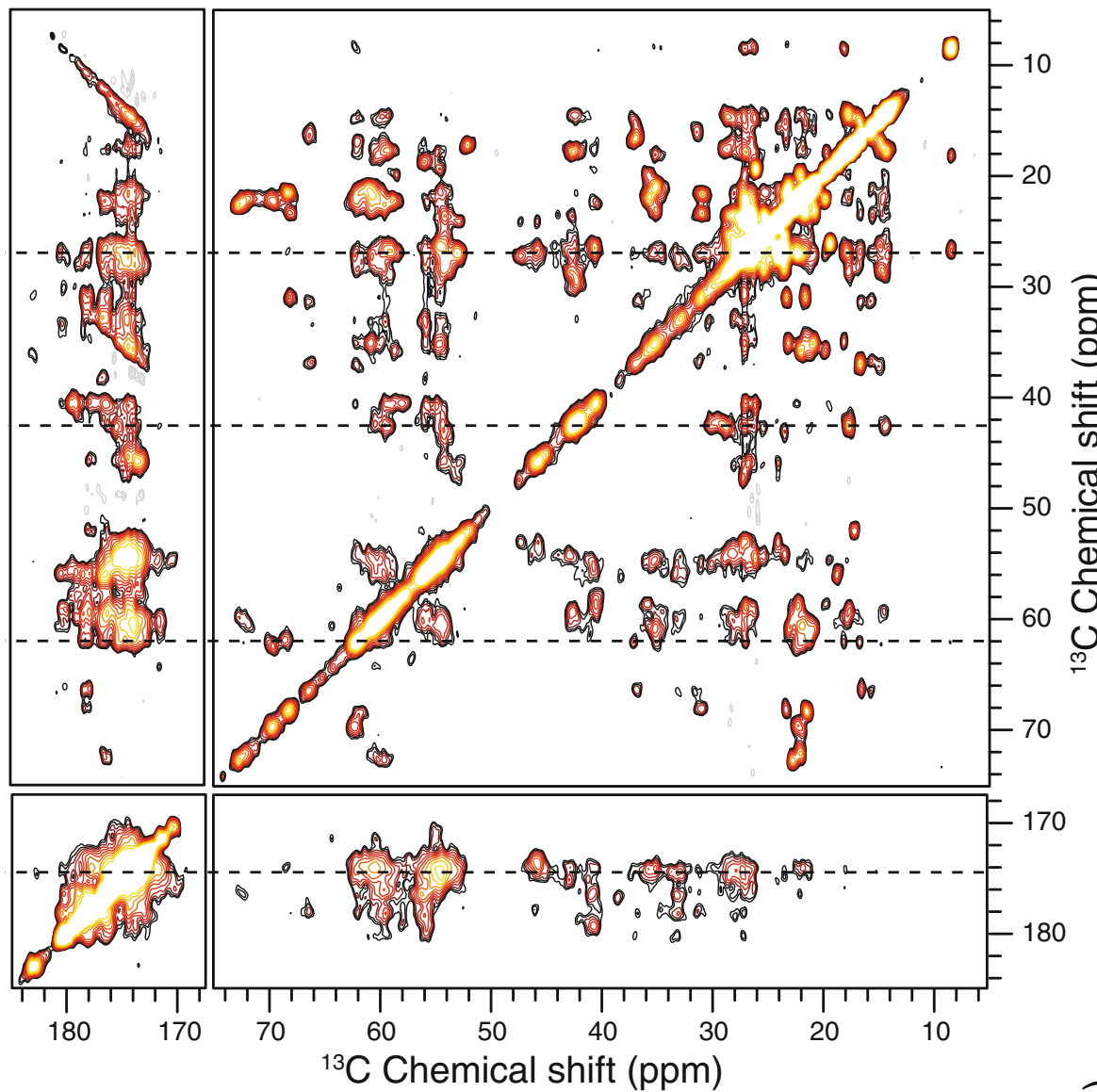

b

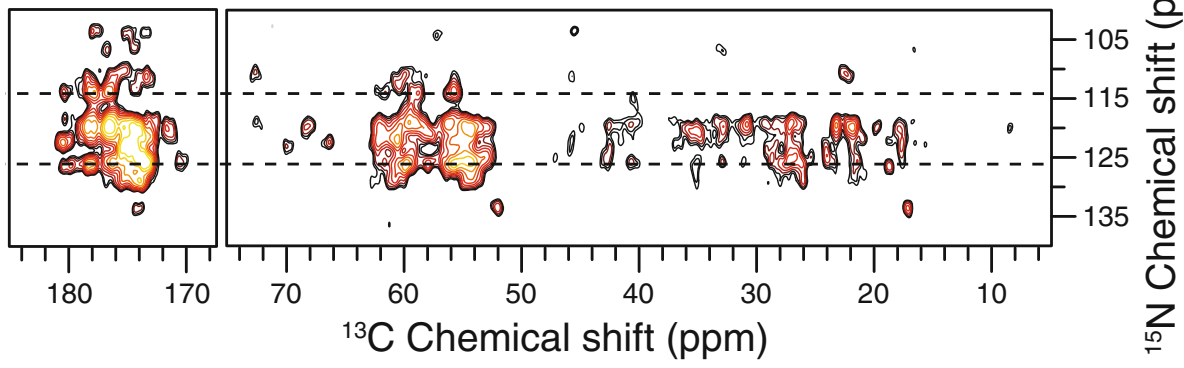


All data presented were acquired at a spinning frequency of $19 \mathrm{kHz}$ on a $9.4 \mathrm{~T}$ wide-bore Bruker Avance-III spectrometer $\left(400 \mathrm{MHz}\right.$ for $\left.{ }^{1} \mathrm{H}\right)$ using a $3.2 \mathrm{~mm}$ triple-resonance MAS probe. To optimize the initial $\mathrm{CP}$ period with simultaneous adiabatic ${ }^{1} \mathrm{H}-{ }^{13} \mathrm{C}$ and ${ }^{1} \mathrm{H}-{ }^{15} \mathrm{~N} \mathrm{CP}$, we used the scheme from Fig. $1 \mathrm{~b}$ where $\mathrm{X}$ is the detection channel $\left({ }^{13} \mathrm{C} /{ }^{15} \mathrm{~N}\right)$ and $\mathrm{Y}$ refers to the "third" channel $\left({ }^{15} \mathrm{~N} /{ }^{13} \mathrm{C}\right)$. Our experiments use identical contact times for the two CP processes, although this could be changed by storing the magnetization for either $\mathrm{X}$ or $\mathrm{Y}$ along the $\mathrm{z}$-direction during part of the contact time. For the simple model peptide $\quad \mathrm{U}-\left[{ }^{13} \mathrm{C},{ }^{15} \mathrm{~N}\right]-\mathrm{N}-\mathrm{f}-\mathrm{MLF}-\mathrm{OH} \quad(\mathrm{N}-\mathrm{f}-$ MethionineLeucine-Phenylalanine-OH) diluted to $10 \%$ in material with natural isotopic abundance) both channels $\left({ }^{15} \mathrm{~N}\right.$ and ${ }^{13} \mathrm{C}$ ) show near-optimum transfer at the same contact time for both ${ }^{1} \mathrm{H}-{ }^{13} \mathrm{C}$ and ${ }^{1} \mathrm{H}-{ }^{15} \mathrm{~N}$ CP (see Supplementary Figures $\mathrm{S} 1 \mathrm{a}$ and $\mathrm{b}$ ), but a compromise may have to be found in other systems. We have further investigated the $\mathrm{CP}$ dynamics for the model protein ubiquitin. The sample was prepared as described in (Manolikas et al. 2008) and a $3.2 \mathrm{~mm}$ rotor was filled using an ultracentrifuge with approximately $15 \mathrm{mg}$ of protein (Böckmann et al. 2009). While the CP-buildup dynamics are almost identical for individual transfer to only ${ }^{15} \mathrm{~N}$ or ${ }^{13} \mathrm{C}$ transfer (black curves in Fig. 2a, b) and for simultaneous transfer (red curves), the optimum mixing time is clearly longer for ${ }^{15} \mathrm{~N}$ compared to ${ }^{13} \mathrm{C}$. Hence, a compromise has to be made for the mixing time for simultaneous CP depending on which nuclei one wants to obtain the higher signal intensity for. Typically, in a protein, the PAIN experiment is less sensitive than the PAR experiment and, therefore, the $\mathrm{CP}$ may often be optimized for the ${ }^{1} \mathrm{H}-{ }^{15} \mathrm{~N}$ transfer. The small sensitivity loss seen between the red and black curves $(<5 \%)$ is attributed to the limited number of protons (more precisely the limited heat capacity of the proton system).

Figure 2c, d illustrate the signal loss for simultaneous detection when compared to the individually optimized ${ }^{1} \mathrm{H}-{ }^{13} \mathrm{C}$ and ${ }^{1} \mathrm{H}-{ }^{15} \mathrm{~N}$ CP. For the simultaneous $\mathrm{CP}$ we chose a contact time of $1.0 \mathrm{~ms}$, the ${ }^{1} \mathrm{H}-{ }^{13} \mathrm{C}$ and ${ }^{1} \mathrm{H}-{ }^{15} \mathrm{~N}$ contact times were optimized to be 0.6 and $1.6 \mathrm{~ms}$, respectively. The individual CP spectra are given as black traces, the loss in simultaneous CP in green. The major contribution to the loss arises from the compromise in mixing time but the signal intensity per unit time is still significantly higher than for the conventional method.

Employing the pulse sequence in Fig. 1a, two PAR/ PAIN experiments with a $\pi$ phase change on $\varphi_{2}$ have been measured for ubiquitin. Figure 3 shows the experimental PAR spectra, obtained by addition of the raw spectra (Fig. 3a) and of the PAIN spectrum, obtained by subtraction (Fig. 3b). The two raw data sets are presented in supporting material Figure S2. The simultaneous PAR and PAIN mixing period was set to $5 \mathrm{~ms}$. The $\mathrm{rf}$ amplitudes were optimized in two steps. The first step was to determine the PAR condition and, in the second step, the ${ }^{15} \mathrm{~N} \mathrm{rf}$ field strength was optimized for ${ }^{15} \mathrm{~N}-{ }^{13} \mathrm{C}$ transfer. The simultaneous experiment involves identical mixing times for the PAR and PAIN transfer but usually, optimal mixing

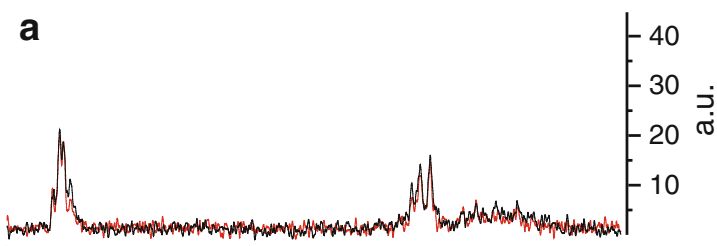

b

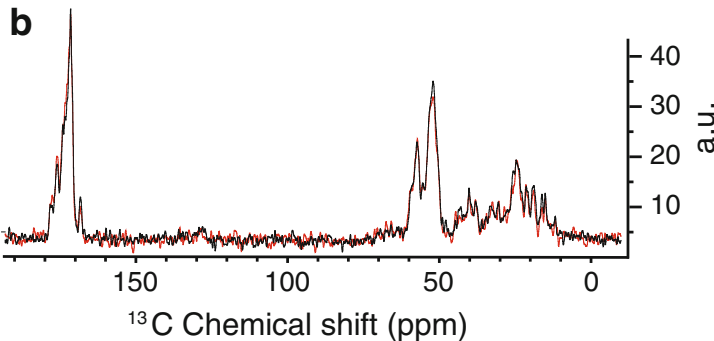

Fig. 4 A comparison of 1D traces from 2D PAIN (a) and (b) and PAR (c) and (d) correlation spectra are shown. The red traces are taken from the 2D spectra shown in Fig. 3a, b. The black traces are taken from individually optimized and measured PAR and PAIN

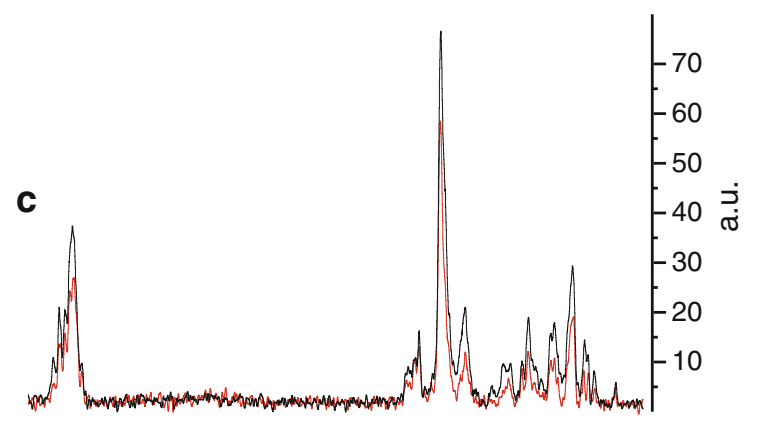

d

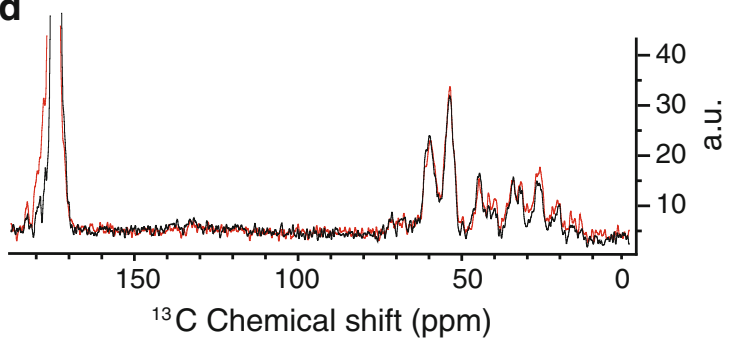

spectra. The position of the traces in the indirect dimension are marked by broken lines in Fig. 3a, b (114.6 ppm (a), 125.7 ppm (b), $61.8 \mathrm{ppm}(\mathbf{c})$ and $174.5 \mathrm{ppm}(\mathbf{d}))$ 
times for these experiments are similar, typically $2-10 \mathrm{~ms}$ in uniformly labeled samples.

To investigate the relative sensitivity of individually sampled PAR and PAIN experiments (see supporting material Figure S3) and the simultaneous experiment, we compare one-dimensional traces out of the 2D spectra. For the PAIN experiments, two representative traces are shown in Fig. 4a, b (in red for the simultaneous experiment, in black for a conventional PAIN). The signal loss for the PAIN spectrum from the simultaneous experiment is almost constant over the spectrum and everywhere smaller than $15 \%$. This signal loss is accounted for by the CP-efficiency, and could be further reduced at the cost of the PAR intensity, as discussed in the context of Fig. 2. For the 2D PAR spectrum from the simultaneous experiment a somewhat stronger signal loss of up to $30 \%$ for selected traces (and 50\% for a few peaks) is seen in Fig. 4c where a trace with a $\delta_{1}$ frequency in the ${ }^{13} \mathrm{C}_{\alpha}$ region $(61.8 \mathrm{ppm})$ is shown. About half of the signal loss is explained by the initial CP (see Fig. 2c) and we attribute the additional loss to magnetization to polarization transfer to the ${ }^{15} \mathrm{~N}$ spins during mixing (inverse PAIN process). For all other resonances (carbonyl and side-chain ${ }^{13} \mathrm{C}$ ) the signal is approximately the same for simultaneous and conventional experiments because the PAIN-type loss is smaller. This finding is illustrated in Fig. 4d and Figure S4, respectively.

As mentioned above, we chose a concurrent $\mathrm{CP}$ mixing time of $1.0 \mathrm{~ms}$ for acquiring simultaneous PAR and PAIN spectra in order to maximize overall signal intensity. Usually, the PAIN spectrum has the lowest sensitivity and for practical applications it might be more beneficial to optimize the CP time for the ${ }^{15} \mathrm{~N}$ CP transfer. Under such conditions, the PAIN part from the simultaneous experiment has a negligible intensity loss compared to a separate PAIN experiment $(<5 \%)$ and a good PAR spectrum is obtained simultaneously "for free".

In conclusion, we have introduced a scheme for simultaneous recording of 2D PAR and PAIN spectra. The scheme allows us to obtain a PAR spectrum as a byproduct while recording a PAIN spectrum without compromising the sensitivity of the PAIN spectrum. Using ubiquitin it is experimentally shown, that efficient PAR and PAIN transfer are indeed fulfilled concurrently and that simultaneous ${ }^{13} \mathrm{C}-{ }^{13} \mathrm{C}$ and ${ }^{15} \mathrm{~N}-{ }^{13} \mathrm{C}$ coherence transfer takes place. In our example, the reduction in experimental time was $40 \%$ when compared to the time to separately record PAIN and PAR spectra with the small signal-to-noise ratio. Depending on relaxation times, the scheme allow saving up to $50 \%$ of the magnet time in biological applications.

Acknowledgments This work was supported by the Swiss National Science Foundation (Grant 200020_134681).The European Commission under the Seventh Framework Program (FP7), contract Bio-NMR 261863 and the Danish National Research Foundation.

\section{References}

Bayro MJ, Huber M, Ramachandran R, Davenport TC, Meier BH, Ernst M, Griffin RG (2009) Dipolar truncation in magic-angle spinning NMR recoupling experiments. J Chem Phys 130(11):114506

Bertini I, Bhaumik A, De Paepe G, Griffin RG, Lelli M, Lewandowski JR, Luchinat C (2010) High-resolution solid-state NMR structure of a 17.6 kDa protein. J Am Chem Soc 132(3):1032-1040

Böckmann A (2008) 3D protein structures by solid-state NMR spectroscopy: ready for high resolution. Angew Chem Int Ed Engl 47(33):6110-6113

Böckmann A, Gardiennet C, Verel R, Hunkeler A, Loquet A, Pintacuda G, Emsley L, Meier BH, Lesage A (2009) Characterization of different water pools in solid-state NMR protein samples. J Biomol NMR 45(3):319-327

Cady SD, Schmidt-Rohr K, Wang J, Soto CS, Degrado WF, Hong M (2010) Structure of the amantadine binding site of influenza M2 proton channels in lipid bilayers. Nature 463(7281):689-692

Castellani F, van Rossum B, Diehl A, Schubert M, Rehbein K, Oschkinat H (2002) Structure of a protein determined by solidstate magic-angle- spinning NMR spectroscopy. Nature 420(6911):98-102

De Paepe G, Lewandowski JR, Loquet A, Bockmann A, Griffin RG (2008) Proton assisted recoupling and protein structure determination. J Chem Phys 129(24):245101-245122

De Paepe G, Lewandowski JR, Loquet A, Eddy M, Megy S, Böckmann A, Griffin RG (2011) Heteronuclear proton assisted recoupling. J Chem Phys 134(9):095101-095119

Ferguson N, Becker J, Tidow H, Tremmel S, Sharpe T, Krause G, Flinders J, Petrovich M, Berriman J, Oschkinat H, Fersht A (2006) General structural motifs of amyloid protofilaments. PNAS 103:16248-16253

Franks W, Wylie B, Frericks Schmidt H, Nieuwkoop A, Mayrhofer R-M, Shah G, Graesser D, Rienstra CM (2008) Dipole tensor-based atomic-resolution structure determination of a nanocrystalline protein by solid-state NMR. Proc Nat Acad Sci 105:4621-4625

Franks WT, Atreya HS, Szyperski T, Rienstra CM (2010) GFT projection NMR spectroscopy for proteins in the solid state. J Biomol NMR 48(4):213-223

Gath J, Habenstein B, Bousset L, Melki R, Meier BH, Böckmann A (2011) Solid-state NMR sequential assignments of $\alpha$-synuclein. Biomol NMR Assign. doi:10.1007/s12104-011-9324-3

Grommek A, Meier BH, Ernst M (2006) Distance information from proton-driven spin diffusion under MAS. Chem Phys Lett 427(4-6):404-409

Habenstein B, Wasmer C, Bousset L, Sourigues Y, Schütz A, Loquet A, Meier BH, Melki R, Böckmann A (2011) Extensive de novo solid-state NMR assignments of the $33 \mathrm{kDa}$ C-terminal domain of the Ure2 prion. J Biomol NMR 51(3):235-243

Hediger S, Meier BH, Ernst RR (1995) Adiabatic passage HartmannHahn cross polarization in NMR under magic angle sample spinning. Chem Phys Lett 240(1):449-456

Herbst C, Riedel K, Ihle Y, Leppert J, Ohlenschläger O, Görlach M, Ramachandran R (2008) MAS solid state NMR of RNAs with multiple receivers. J Biomol NMR 41:121-125

Higman VA, Flinders J, Hiller M, Jehle S, Markovic S, Fiedler S, van Rossum B-J, Oschkinat H (2009) Assigning large proteins in the solid state: a MAS NMR resonance assignment strategy using selectively and extensively 13C-labelled proteins. J Biomol NMR 44(4):245-260 
Huber M, Hiller S, Schanda P, Ernst M, Böckmann A, Verel R, Meier BH (2011) A proton-detected 4D solid-state NMR experiment for protein structure determination. ChemPhysChem 12(5):915-918

Iwata K, Fujiwara T, Matsuki Y, Akutsu H, Takahashi S, Naiki H, Goto Y (2006) 3D structure of amyloid protofilaments of $\beta 2$ microglobulin fragment probed by solid-state NMR. PNAS 103:18119-18124

Jaroniec C, MacPhee C, Bajaj V, McMahon M, Dobson C, Griffin R (2004) High-resolution molecular structure of a peptide in an amyloid fibril determined by magic angle spinning NMR spectroscopy. PNAS 101(3):711-716

Jehle S, Rajagopal P, Bardiaux B, Markovic S, Kühne R, Stout JR, Higman VA, Klevit RE, van Rossum B-J, Oschkinat H (2010) Solid-state NMR and SAXS studies provide a structural basis for the activation of alphaB-crystallin oligomers. Nat Struct Mol Biol 17(9):1037-1042

Lange A, Becker S, Seidel K, Giller K, Pongs O, Baldus M (2005) A concept for rapid protein-structure determination by solid-state NMR spectroscopy. Angew Chem Int Edit 44(14):2089-2092

Lange V, Becker-Baldus J, Kunert B, van Rossum B-J, Casagrande F, Engel A, Roske Y, Scheffel FM, Schneider E, Oschkinat H (2010) A MAS NMR study of the bacterial ABC transporter ArtMP. ChemBioChem 11(4):547-555

Lewandowski JR, De Paepe G, Griffin RG (2007) Proton assisted insensitive nuclei cross polarization. J Am Chem Soc 129(4):728-729

Lewandowski JR, De Paëpe G, Eddy MT, Struppe J, Maas W, Griffin RG (2009) Proton assisted recoupling at high spinning frequencies (dagger). J Phys Chem B 113(27):9062-9069

Linser R, Bardiaux B, Higman V, Fink U, Reif B (2011) Structure calculation from unambiguous long-range amide and methyl $1 \mathrm{Hâ}$ ' $1 \mathrm{H}$ distance restraints for a microcrystalline protein with MAS solid-state NMR spectroscopy. J Am Chem Soc 133(15):5905-5912

Loquet A, Bardiaux B, Gardiennet C, Blanchet C, Baldus M, Nilges M, Malliavin T, Böckmann A (2008) 3D structure determination of the Crh protein from highly ambiguous solid-state NMR restraints. J Am Chem Soc 130(11):3579-3589

Mani R, Tang M, Wu X, Buffy JJ, Waring AJ, Sherman MA, Hong M (2006) Membrane-bound dimer structure of a $\beta$-Hairpin antimicrobial peptide from rotational-echo double-resonance solidstate NMR. Biochemistry 45(27):8341-8349

Manolikas T, Herrmann T, Meier BH (2008) Protein structure determination from C-13 spin-diffusion solid-state NMR spectroscopy. J Am Chem Soc 130(12):3959-3966
Nielsen JT, Bjerring M, Jeppesen MD, Pedersen RO, Pedersen JM, Hein KL, Vosegaard T, Skrydstrup T, Otzen DE, Nielsen NC (2009) Unique identification of supramolecular structures in amyloid fibrils by solid-state NMR spectroscopy. Angewandte Chemie Int Ed 48(12):2118-2121

Nieuwkoop AJ, Wylie BJ, Franks WT, Shah GJ, Rienstra CM (2009) Atomic resolution protein structure determination by threedimensional transferred echo double resonance solid-state nuclear magnetic resonance spectroscopy. J Chem Phys 131(9):095101

Renault M, Bos MP, Tommassen J, Baldus M (2011) Solid-state NMR on a large multidomain integral membrane protein: the outer membrane protein assembly factor BamA. J Am Chem Soc 133(12):4175-4177

Scholz I, Meier BH, Ernst M (2007) Operator-based triple-mode Floquet theory in solid-state NMR. J Chem Phys 127(20):204504-204513

Schütz AK, Soragni A, Hornemann S, Aguzzi A, Ernst M, Böckmann A, Meier BH (2011) The amyloid-congo red interface at atomic resolution. Angew Chem Int Ed Engl 50(26):5956-5960

Todokoro Y, Yumen I, Fukushima K, Kang S-W, Park J-S, Kohno T, Wakamatsu K, Akutsu H, Fujiwara T (2006) Structure of tightly membrane-bound mastoparan-X, a G-protein-activating peptide. Determined by solid-state NMR. Biophys J 91(4):1368-1379

Traaseth NJ, Shi L, Verardi R, Mullen DG, Barany G, Veglia G (2009) Structure and topology of monomeric phospholamban in lipid membranes determined by a hybrid solution and solid-state NMR approach. Proc Natl Acad Sci USA 106(25):10165-10170

van Melckebeke H, Wasmer C, Lange A, Ab E, Loquet A, Böckmann A, Meier BH (2010) Atomic-resolution three-dimensional structure of HET-s(218-289) amyloid fibrils by solid-state NMR spectroscopy. J Am Chem Soc 132(39):13765-13775

Wasmer C, Lange A, Van Melckebeke H, Siemer AB, Riek R, Meier BH (2008) Amyloid fibrils of the HET-s(218-289) prion form a beta solenoid with a triangular hydrophobic core. Science 319(5869):1523-1526

Zhang Y, Doherty T, Li J, Lu W, Barinka C, Lubkowski J, Hong M (2010) Resonance assignment and three-dimensional structure determination of a human $\alpha$-defensin, HNP-1, by solid-state NMR. J Mol Biol 397(2):408-422

Zhou DH, Shea JJ, Nieuwkoop AJ, Franks WT, Wylie BJ, Mullen C, Sandoz D, Rienstra CM (2007) Solid-state protein-structure determination with proton-detected triple-resonance 3D magicangle-spinning NMR spectroscopy. Angew Chem Int Edit 46(44):8380-8383 